\title{
STERILITY MONITORING OF CANINE PACKED RED BLOOD CELLS
}

O. V. YEHOROV, PhD student, Department of Surgery and Pathophysiology named after Academician I. O. Povazhenko https://orcid.org/0000-0002-6095-2244

M. O. MALYUK, Doctor of Veterinary Sciences, Professor, Department of Surgery and Pathophysiology named after Academician I. O. Povazhenko https://orcid.org/0000-0003-3019-6035

H. V. KOZLOVSKA, Candidate of Veterinary Sciences, Associate Professor, Department of Epizootology, Microbiology and Virology https://orcid.org/0000-0003-1149-9970 National University of Life and Environmental Sciences of Ukraine, 15 Heroiv Oborony st., Kyiv 03041, Ukraine E-mail:o.yehorov@it.nubip.edu.ua; nikolai_malyuk@ukr.net; kozlovska@nubip.edu.ua

\begin{abstract}
A constant risk factor of transfusion is microbial contamination of whole blood and its components. Because using contaminated blood products can lead to sepsis and high risks to the health of recipients. Blood can be a good nutrient medium for microorganisms, so the risk of bacteria growth in any blood component after it has been donated is significant. Violation in the rules of asepsis during blood donation, processing of blood products, damage to blood collection systems or their tightness, etc. can cause microbial contamination.

We examined 5 samples of preserved canine packed red blood cells. The donor animals were 5 clinically healthy dogs. Blood was collected in closed systems with a CPDA anticoagulant. After following centrifuging, plasma was separated from red blood cells in different containers. The remaining packed red blood cells were stored at a temperature of $+2-6^{\circ} \mathrm{C}$ for 30 days.

The bacteria cultivation method is considered the "gold standard" for assessing the presence of microbial contamination in most blood transfusion centers. The tested canine packed red blood cells samples were inoculated into thioglycolate and Sabouraud media and incubated in a thermostat at $+20-25^{\circ} \mathrm{C}$. The incubation period was 14 days. According to the results of the bacteriological examination of these samples of canine packed red blood cells after their storage, a non-sterile sample was no found.

Thereby, the method of blood collection using closed systems with CPDA anticoagulant is reliable and allows obtaining donor blood and its components without loss of sterility during long-term storage.
\end{abstract}

Keywords: canine packed red blood cells, microbial contamination, donor blood sterility 


\section{Introduction}

This work is a continuation of a series of our studies on animal transfusion, in which we study the effect of blood sampling techniques and type of using systems on the sterility of animals' canned whole blood and blood components during long-term storage under hypothermic conditions (Yehorov et al., 2020).

Bacterial contamination of animals' donor blood and blood components always are high risk and a problem of clinical veterinary transfusion. The probability of contamination exists at all stages of blood sampling and processing of its components. For assessing the quality and safety of such preparations, it is important to control sterility by microbiological tests (Ischenkova et al., 2015).

Sterility monitoring of canned animals' blood and blood components needs to identify possible contamination by aerobic and anaerobic microorganisms. The reason for this is the permanent risk of iatrogenic factors even all rules of asepsis during blood collection and storage are complied, and microbial contamination can further endanger the health and life of animal recipients (Lyubich, 2014).

Frequent reasons for microbial contamination of blood components during their processing may be leaks in any part of containers or improper techniques during plasma extraction or division of the volume of the transfusion preparation into several doses (Lasta et al., 2020).

Contamination is also possible during blood sampling from donors. Thus, there have been reported cases of microbial contamination of collected blood with $S$. Marcescens, when using inappropriate concentrations of disinfectant solutions for treating the animal skin at the site of blood sampling (Miglio et al., 2016).

\section{Analysis of recent researches and publications}

Before using, blood components usually are visually inspected and bacterial infection should be suspected when there is a discoloration of the component, hemolysis of the upper layers of red blood cells, or presence of visible clots. If such signs are detected, a bacteriological examination of this unit should be provided to determine if contamination occurred (Rodrigues et al., 2020).

The bacteria cultivation method is considered the "gold standard" for assessing blood contamination in most blood transfusion centers.

The process of bacterial culture growth is slow because microorganisms need time to develop and reach a significant number of cells. For this reason, it is possible to use an alternative PCR method because its analytical sensitivity is higher and the time required to obtain the result is much shorter (Wardrop et al., 2005).

However, the virulence of contaminating microorganisms determines their ability to grow under storage conditions. Only the presence of bacteria in the blood is less important than their ability to replicate, which causes serious septic complications in patients (Miglio et al., 2016).

During testing sterility of blood transfusion preparations, the possibility of microorganisms detecting is directly proportional to their number in the test sample and depends on the ability of these microorganisms to grow on the nutrient media with visible signs. At a low degree of contamination, the probability of detecting microorganisms is very low, even in the case of uniform microbial contamination.

Therefore, the purpose of the sterility test is to prove the absence of viable microorganisms in the blood component sample with maximum reliability. The 
main factors that determine the effectiveness of sterility monitoring are the testing sample volume, seeding technique, nutrient composition, time, and temperature of culture incubation (Lyubich, 2014).

Purpose. The purpose of the study is to test the sterility of canine packed red blood cells during quality control of these blood components after long-term hypothermic storage.

\section{Materials and methods of research}

The material for the study was samples of packed red blood cells that were collected from 5 blood donor dogs. Donor animals were clinically healthy.

Blood was collected from the jugular vein of dogs by closed systems (Fig. 1).

Before donation, a puncture site was shaved and treated with $70 \%$ alcohol. Donor blood from dogs was collected in double polymer containers with CPDA anticoagulant (sodium citrate, sodium phosphate, dextrose, adenine) (Kisielewicz \& Self, 2014).
The volume of blood sampling was calculated at $12 \mathrm{~cm}^{3}$ per $1 \mathrm{~kg}$ of animal weight. This amount minimizes unwanted donor cat risks during blood collection (blood pressure and heart rate) and after donation (Helm \& Knottenbelt, 2010).

All blood samples were typed by a test "RapidVet-H Canine DEA 1". All animals in this study had a DEA 1.1 negative blood group (Proverbio et al., 2019). For morphological analysis of canine donor whole blood, we tested samples by automatic Mindray BC2800 hematology analyzer, the main results are shown in Table 1.

After blood collection, the double containers were centrifuged at $2500 \mathrm{rpm}$ for 20 minutes on Hettich ROTANTA 460R centrifuge. After that, blood plasma was separated from the red blood cells in different containers by a plasma extractor with keeping the system closed (Guide, 2013) (Fig. 2).

The erythrocyte mass of canine blood, or canine packed red blood cells ( $\mathrm{pRBC}$ ), was stored at a temperature of $+2-6{ }^{\circ} \mathrm{C}$ for 30 days in VESTFROST AKG 317 refrigerator in the

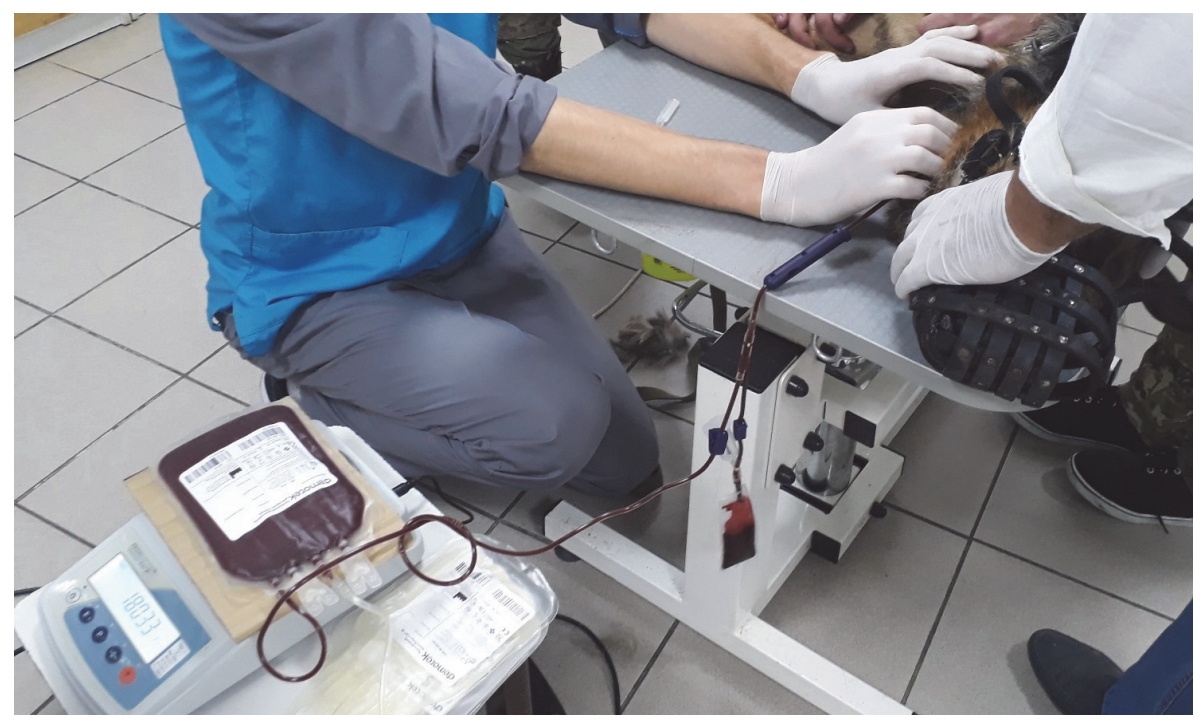

Fig. 1. Blood sampling using a closed system in a dog 


\section{The results of hematology analysis in donor $\operatorname{dogs}(M \pm m, n=5)$}

\begin{tabular}{|c|c|c|c|}
\hline Red blood cells, $10^{12} / \mathrm{L}$ & Hemoglobin, g/L & White blood cells, $10^{9} / \mathrm{L}$ & Hematocrit, \% \\
\hline $7.3 \pm 1.1$ & $175.4 \pm 7.3$ & $9.8 \pm 2.1$ & $52.2 \pm 4.9$ \\
\hline
\end{tabular}

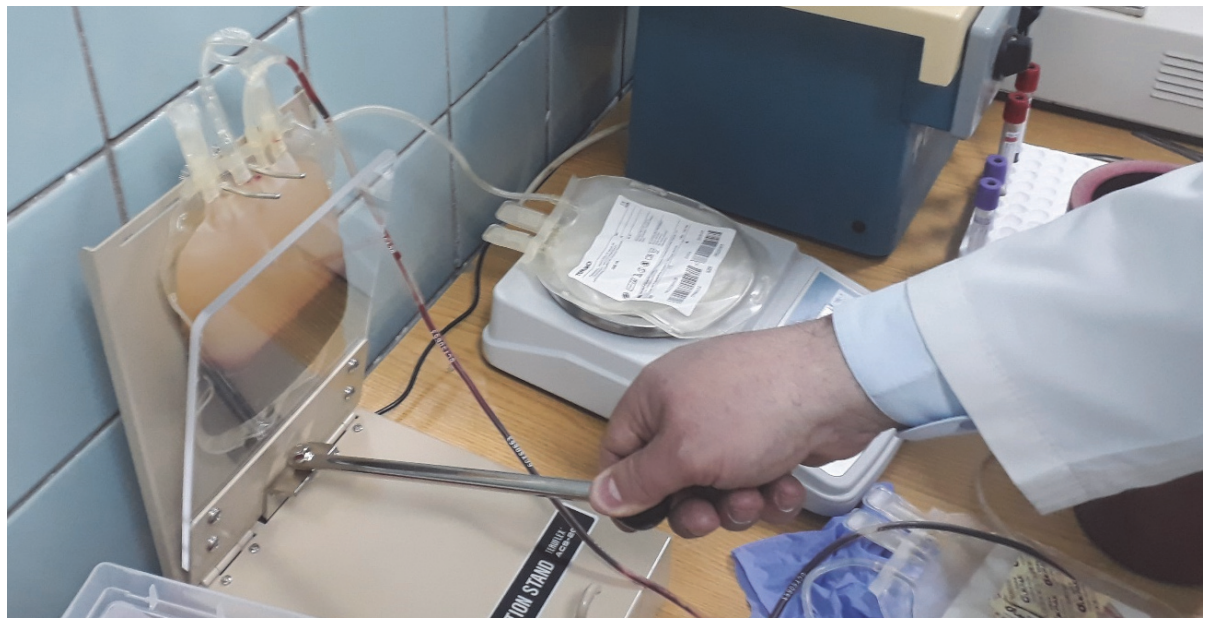

Fig. 2. Separation of blood plasma from red blood cells

educational and scientific laboratory (ESL) "Animals Blood Bank" at the National University of Life and Environmental Sciences of Ukraine (Fig. 3).

Bacteriological examination for sterility of canned pRBC samples was performed according to the approved Instruction of the Ministry of Health of Ukraine (Instruction, 1999) in the laboratory of the Department of Epizootology, Microbiology and Virology at NULES of Ukraine.

For testing, we used sterile pipettes, closed with cotton plugs, rubber bulbs, sterilized tools, which were in a container with $96 \%$ ethanol during manipulation.

Polymer containers with pRBC were checked for leaks in the lab pre-box, then wiped with $70 \%$ ethanol. Before inoculation, we clamped the container tube above the node and cut the tube between the node and clamp. The cut end of the tube was quickly passed through the flame, and a pipette was introduced into it. Reducing the pressure to the clamp, we pressed the container and piped at least $2 \mathrm{~cm}^{3}$ of sample.

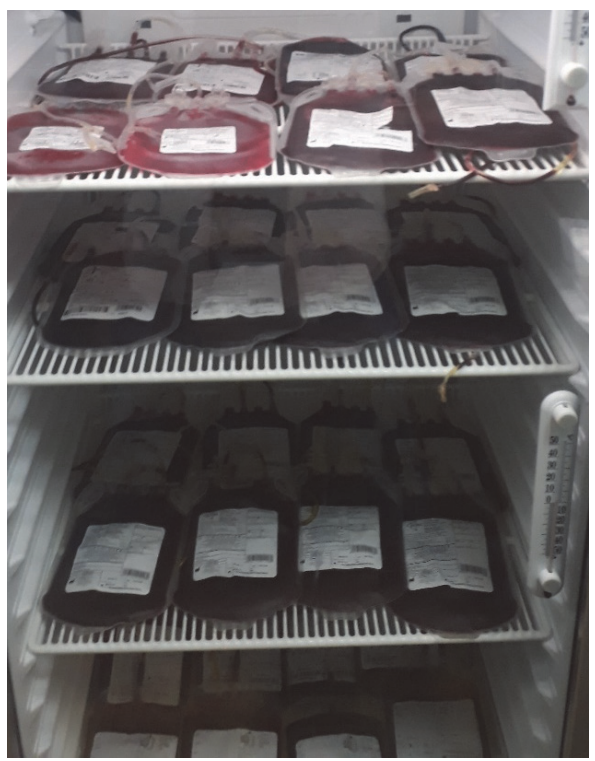

Fig. 3. The refrigerator for $\mathrm{pRBC}$ storage 
Inoculation of each sample was made in a thickness of culture medium without blowing a separate pipette but with a rubber bulb and without previous flame processing. Used pipettes laid in a disinfectant solution.

The tested pRBC sample was inoculated with $1 \mathrm{ml}$ into two tubes containing $20 \mathrm{~cm}^{3}$ of thioglycollate broth and one tube with $20 \mathrm{~cm}^{3}$ of Sabouraud medium. In parallel, two tubes with thioglycolate broth and one with Sabouraud medium were left untreated for controlling the sterility of the nutrient medium during the entire period of samples incubation. Cultures in thioglycolate broth and control tubes were incubated in a thermostat at $20-25^{\circ} \mathrm{C}$ and $30-35^{\circ} \mathrm{C}$, with Sabouraud medium - at $20-25^{\circ} \mathrm{C}$ (Fig. 4). The incubation period was 14 days for both culture media (Instruction, 1999).

Accounting and interpretation of sterility test results were viewed daily. The presence of microorganisms in nutrient media was assessed visually mac-

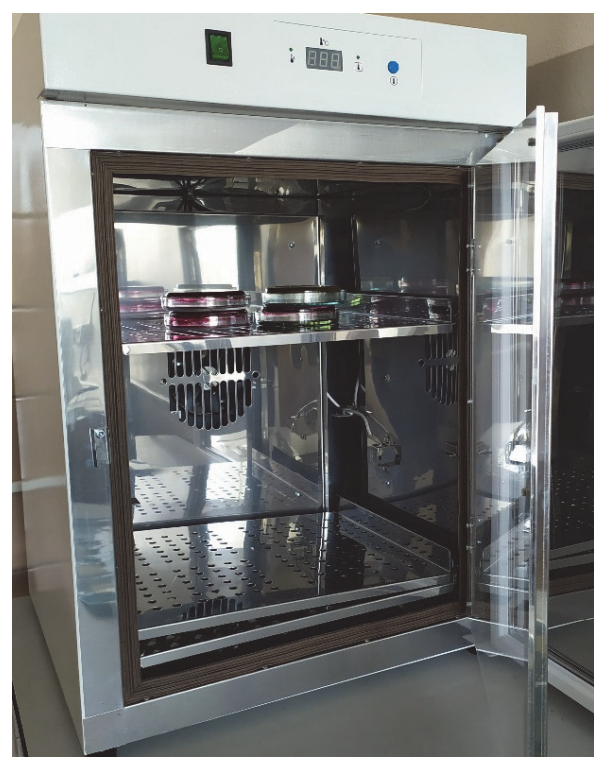

Fig. 4. The thermostat in the Microbiological laboratory roscopically (we looked for turbidity, film, sediment, inclusions) and microscopically.

\section{Results of the research and their discussion}

Currently, in Ukraine, there is no legal regulation of animal blood donation, including the quality control of canned blood and its components. There are few publications on the results of experimental studies of bacterial contamination monitoring during storage of animals' donor blood with CPDA. However, there are similar norms and research in human medicine.

According to the Sterility Control Instruction (Instruction, 1999), sterility monitoring of canned donor blood and its components is one of the main parameters for assessing their quality. This rule applies in the field of human health. Given this, the purpose of our work was aimed to assess the suitability of closed systems for blood collection in dogs and following preparation of $\mathrm{pRBC}$ as a risk factor for bacterial contamination of these preparations during prolonged hypothermic storage.

In total, we examined 5 samples of pRBC from dogs aged 2 to 5 years, which were used as donors in ESL "Animals Blood Bank" of the Department of Surgery and Pathophysiology named after academic I. O. Povazhenko at NULES of Ukraine. The mentioned samples of canine $\mathrm{pRBC}$ were tested after 30 days of refrigeration storage at $+2-6^{\circ} \mathrm{C}$.

During hypothermic storage, an external inspection of polymer containers with test samples of $\mathrm{pRBC}$ showed no signs of bacterial growth: color changes from dark purple to light red or green, signs of red blood cell hemolysis, presence of visible clots. 


\section{The results of $\mathrm{pRBC}$ samples examination for sterility}

\begin{tabular}{|l|c|c|}
\hline The animal & Contamination & The degree of contamination \\
\hline 1 & - & - \\
\hline 2 & - & - \\
\hline 3 & - & - \\
\hline 4 & - & - \\
\hline 5 & - & - \\
\hline
\end{tabular}

Note: "-" - no contamination, "+" - presence of contamination, "*” - low degree, “**” - mild degree, “***” - significant contamination.

The results of the bacteriological examination of $\mathrm{pRBC}$ samples using thioglycolate and Sabouraud media showed that all 5 test samples with a shelf life of 30 days were sterile. The research results were entered into the journal in the form of a table (Table 2).

\section{Conclusions and future perspectives}

The results of our research indicate that closed blood collection systems in dogs with aseptic manipulations are reliable and allow to obtain sterile donor blood and its erythrocyte mass for 30 days.

However, there is a need for further research on the quality of canned canine packed red blood cells to assess the level of hemolysis, red blood cell count, and other indicators to obtain a safe animal transfusion product for a recipient.

\section{References}

Guide to the preparation, use and quality assurance of blood components: Recommendation No. R(95)15, 17th edn, 2013 edition. Strasbourg: Council of Europe.

Helm, J., \& Knottenbelt, C. (2010). Blood transfusion in dogs and cats. 2. Practicalities of blood collection and administration. In Practice, 32, 231-237.

Instruktsiia "Kontrol sterylnosti konservovanoi krovi, yii komponentiv, preparativ, konservovanoho kistkovoho mozku, plazmozamishchuiuchykh ta konservuiuchykh rozchyniv, umov yikh zahotivli" [Instruction "Control of sterility of canned blood, its components, drugs, preserved bone marrow, plasma substitutes and preserving solutions, conditions of their preparation"]. (1999). Kyiv. Ischenkova, I. V., Suspitsyna, E. G. \& Bineeva, E. Ya. (2015). Mykrobnaia kontamynatsyia komponentov krovy y ee klynycheskye posledstvyia. Sovremennye metody profylaktyky mykrobnoi kontamynatsyy v HbU RO "SPK" [Microbial contamination of blood components and its clinical consequences. Modern prevention methods of microbial contamination in GBU RO "SPK"]. Hlavnyi vrach Yuha Rossii, 2(43), 4-5. Kisielewicz, C., \& Self, I. (2014). Canine and feline blood transfusions: controversies and recent advances in administration practices. Veterinary Anaesthesia and Analgesia, 41(3), 233-242.

Lasta, C. S., Hlavac, N., Marcondes, N. A., Dalmolin, M. L., Terra, S. R., de Almeida Lacerda, L., ... \& González, F. H. D. (2020). Quality control in veterinary blood banks: evaluation of canine platelet concentrates stored for five days. BMC veterinary research, 16(1), 1-7.

Lyubich, V. V. (2014). Osoblyvosti mikrobiolohichnykh doslidzhen pid chas vyprobuvan hemotransfuziinykh preparativ na sterylnist [Peculiarities of microbiological investigations during tests of sterility blood transfusion drugs]. Hematolohiia i perelyvannia krovi, 37, 293-301. Miglio, A., Stefanetti, V., Antognoni, M. T., Cappelli, K., Capomaccio, S., Coletti, M., \& Passamonti, F. (2016). Stored canine whole blood units: what is the real risk of bacterial 
contamination? Journal of veterinary internal medicine, 30(6), 1830-1837.

Morris, J. L., Bloch, C. P., \& Brabson, T. L. (2021). The effect of time on packed cell volume following packed red blood cell transfusion in anemic dogs. Journal of Veterinary Emergency and Critical Care, 31(2), 215-220.

Proverbio, D., Perego, R., Baggiani, L., \& Spada, E. (2019). A card agglutination test for dog erythrocyte antigen 1 (DEA 1) blood typing in donor dogs: Determining an appropriate cutoff to detect positivity using a receiver operating characteristic curve. Veterinary clinical pathology, 48(4), 630-635.

Rodrigues, R. R., Kayano, C. Y., Dos Santos, V. P., Moroz, L. R., Fantoni, D. T., \& Ambrosio, A. M. (2020). Evaluation of hematologic, biochem- ical, and blood gas variables in stored canine packed red blood cells, and the impact of storage time on blood recipients. Veterinary Clinical Pathology, 49(2), 198-206.

Wardrop, K. J., Reine, N., \& Birkenheuer, A. (2005). Canine and feline blood donor screening for infectious diseases. Journal of Veterinary Internal Medicine, 19, 135-142.

Weeks, J. M., Motsinger-Reif, A. A., \& Reems, M. M. (2021). In vitro iatrogenic hemolysis of canine packed red blood cells during various rapid transfusion techniques. Journal of Veterinary Emergency and Critical Care, 31(1), 25-31.

Yehorov, O. V., Malyuk, M. O., \& Kozlovska, H. V. (2020). Sterility monitoring of cat stored donor blood. Ukrainian Journal of Veterinary Sciences, 11(1), 143-152.

\section{О. В. Єгоров, М. О. МалюК, Г. В. КозЛовСьКа (2021). КОНТРОЛЬ СТЕРИЛЬНОСТІ КОНСЕРВОВАНОÏ ЕРИТРОЦИТАРНОЇ МАСИ СОБАК. Ukrainian Journal of} Veterinary Sciences, 12(2): 67-73, https://doi.org/10.31548/ujvs2021.02.007

Анотація. Під час проведення трансрузії цільною кров'ю та препаратами крові постійним ризиком $\epsilon$ фактор їхнього мікробного забруднення. Адже застосування контамінованих препаратів крові може спричиняти сепсис та високі ризики для здоров'я реципієнтів. Кров може бути живильним середовищем для мікроорганізмів, тому досить значним $\epsilon$ ризик росту кількості бактерій у будь-якому компоненті крові після ії відбору. До мікробного забруднення може призвести порушення правил асептики під час забору донорської крові, виготовлення препаратів крові, пошкодження систем забору крові, їхньої герметичності тощо.

Було досліджено 5 проб консервованої еритроцитарної маси собак. Тваринами-донорами були 5 клінічно здорових собак. Кров відбирали з використанням закритих систем із антикоагулянтом ЦФДА. Після наступного центрифугування плазму відокремлювали від еритроцитів у інший контейнер. Еритроцитарну масу, що залишалася, зберігали за температури $+2-6^{\circ} \mathrm{C}$ продовж 30 діб.

Метод посіву бактерій розглядається як «золотий стандарт» для оцінювання наявності мікробного забруднення в більшості центрів переливання крові. Досліджувані зразки еритроцитарної маси собак інокулювали в тіогліколеве середовище та середовище Сабуро й інкубували в термостаті за 20-25 ㄷ. Інкубаційний період становив 14 діб. За результатами бактеріологічного дослідження проб еритроцитарної маси собак після їхнього зберігання, жодної нестерильної проби не було виявлено.

Отже, метод забору крові з використанням закритих систем, що містять антикоагулянт ЦФДА, є надійним і дає змогу одержувати донорську кров та компоненти крові без втрати стерильності за тривалого терміну зберігання.

Ключові слова: еритроцитарна маса крові собак, мікробна контаміначія, стерильність донорської крові 